\title{
Elemental Composition of Selected Inorganic Fertilizers in Zaria by XRF Method: A Source of Possible Environmental Contamination
}

\author{
Elisha J. J ${ }^{\mathrm{a}}$ \\ ${ }^{a}$ Centre for Biotechnology, Research and Training, Ahmadu Bello University Zaria, Kaduna State, Nigeria.
}

\begin{abstract}
Elemental composition of nine randomly selected inorganic fertilizers purchased from Samaru Zaria, were analyzed using $X$-ray fluorescence spectrometric techniques. The analytical results show that the average concentrations of some toxic elements $(\mathrm{Cr}, \mathrm{Ni}, \mathrm{Si}, \mathrm{V}$, and $\mathrm{Zn}$ ) were within the ranges in agricultural soils, except for Sambuka fertilizer which recorded average Cr concentration higher than found in agricultural soils.

Key words: Elemental composition, Environmental Contamination, Inorganic Fertilizers, XRF
\end{abstract}

\section{Introduction}

Fertilizers are very important in agriculture for sustaining soil fertility and productivity. They however, may constitute one source of heavy metals to the environment in addition to other sources of anthropogenic activities such as mining, smelting, steel, iron and chemical industries (Susie et al., 2001). Among these fertilizers, NPK (Nitrogen- Phosphorous-Potassium) are the major components in association with natural radioactive materials (Uranium-234, Thorium-232, and Potassium-40) transferred from phosphate ore during production. These could emit alpha, beta or gamma radiation. The addition of these plant nutrients may affect the environment by contaminating it with heavy metals and radioactive materials (Santos et al., 1975), and this could be harmful to organisms and damaging to the soil (GRPC, 1977). The exposure to heavy metals and radioactive materials has been associated with some health problems because of their toxicity when they are not metabolized by the body. They accumulate in the body especially in vital organs. For example the accumulation of lead in human body is associated with developmental problem in children. Exposure to high levels of lead, gold and mercury has been associated with autoimmunity, a condition in which the immune system destroys its cells, mistaking them for foreign invaders (Janet Glover-Kervliet, 1995)

Heavy metals in the soil can runoff into water bodies and also percolate into underground water thus affecting food, microorganisms and plant growth (Popescu et al., 2009). Heavy metals get into the body through food when plants take them from the soil. They may accumulate in plant parts and eventually be taken in by humans through the food chain. Chromium is highly persistent in the soil and can affect plant growing conditions and result in accumulation in the soil. The presence of heavy metals in the soil can increase soil acidity and decrease the solubility of beneficial elements like Zinc. Chromium is easily absorbed from the soil by corn and wheat which means, our food supply is at risk of contamination by toxic substances that threaten human life. In Nigeria, just as in other parts of the world, NPK fertilizers are annually used to improve the productivity of the croplands, thus exposing our croplands to the danger of contamination by heavy metals and radioactive materials. The objective of this study was to determine the presence and concentrations of heavy metals and other elements added to our croplands from excessive use of NPK fertilizers by the use of X-Ray Fluorescence Spectrometry.

\subsection{Sample Materials}

\section{Experimental}

Six brands of NPK fertilizers (Sambuka 15-15-15-15, Golden 15-15-15, AFCUTT 15-15-15, Tak 2010-10, Maishaho 20-10-10 and Golden 20-10-10), two brands of Single Super Phosphate (Tak Agro SSP 18\% and FSFC SSP18\%) and one Diammonium Phosphate fertilizers were purchased from Samaru Zaria, Sabon Gari Local Government Area Kaduna State, Nigeria. The samples were transferred into polythene bags, labelled and taken to Centre for Energy Research and Training, Ahmadu Bello University, Zaria laboratory for analysis.

\subsection{Procedure for sample analysis}

\subsubsection{X-Ray Fluorescence (XRF)}

The PW 4030 X-ray Spectrometer (Mini Pal 4 version) in the Centre for Energy Research and Training, Zaria was used. It is an energy dispersive microprocessor controlled analytical instrument designed for the detection and the measurement of elements in samples (solids, powders, and liquids). The samples were weighed and ground in agate mortar and a binder (PVC dissolved in Toluene) was added to the samples, 
carefully mixed and pressed in a hydraulic press into a $100 \mathrm{mg} / \mathrm{cm}^{2}$ pellet. The pellet was loaded in the sample chamber of the spectrometer and a voltage (30KV maximum) and a current ( $1 \mathrm{~mA}$ maximum) were applied to produce the X-rays to excite the sample for a preset time (10minutes in this case). The spectrum from the sample was then analyzed to determine the concentration of the elements in the sample.

The analysis of variance was used in comparing the concentration of the metals in the fertilizers; the mean levels of concentration of the metals in the different fertilizers are compared. Letters along the means indicate classes of significant differences.

\section{Results and discussions}

The elemental composition of nine inorganic fertilizers determined by X-Ray Fluorescence method is shown in Table 1. Silicon recorded a mean of $8,148 \mathrm{mg} / \mathrm{kg}$ with the highest value of $20,400 \mathrm{mg} / \mathrm{kg}$ recorded for Tak Agro 18\% SSP. It was not detected in Golden 15-15-15 NPK. The high concentration of Si in the Tak Agro18\% SSP could be due to adulteration, while the FSFC 18\% SSP that might not have been adulterated recorded the absence of $\mathrm{Si}$ in its composition. Vanadium recorded a mean of $29.0 \mathrm{mg} / \mathrm{kg}$ the highest concentration was recorded for Tak Agro SSP $18 \%$ at $58 \mathrm{mg} / \mathrm{kg}$. The Vanadium concentration ranged from BDL to $58 \mathrm{mg} / \mathrm{kg}$ with a mean of $29 \mathrm{mg} / \mathrm{kg}$. The highest Vanadium concentration was recorded by Tak Agro SSP $18 \%$ fertilizer sample.

The lowest concentration was recorded for Golden 15-15-15 NPK. Vanadium was not detected in FSFC SSP18\% and AFCUTT 15-15-15 NPK which could have been eliminated when the phosphate ore was processed. Chromium was not detected in FSFC SSP18\%. The mean concentration was $34.0 \mathrm{mg} / \mathrm{kg}$ with the highest concentration recorded for Sambuka 15-15-15 NPK at $72.0 \mathrm{mg} / \mathrm{kg}$ the remaining inorganic fertilizers recorded concentrations below $50.0 \mathrm{mg} / \mathrm{kg}$.

The concentration of chromium in the soil is $2-60 \mathrm{mg} / \mathrm{kg}$ (Kabata- Pendias \& Pendias, 1984). The concentration found in Sambuka $72 \mathrm{mg} / \mathrm{kg}$ is higher than the maximum concentration in soils. This fertilizer should not be chosen for soils recording maximum $60 \mathrm{mg} / \mathrm{kg}$ concentrations of Chromium to avoid Chromium build up in the soil.

Titanium was also detected in all the inorganic sample fertilizers at a mean of $631 \mathrm{mg} / \mathrm{kg}$. Aluminium was not detected in Sambuka 15-15-15 NPK, Golden 15-15-15 NPK and in DAP. The range was BDL to $110,400 \mathrm{mg} / \mathrm{kg}$. The mean concentration of Aluminium in the inorganic fertilizer samples was $44,221 \mathrm{mg} / \mathrm{kg}$. The AFCUTT 15-15-15 NPK recorded the highest Aluminium concentration of $110,400 \mathrm{mg} / \mathrm{kg}$.

The danger of high concentrations of Aluminium in the soil is not only its toxicity but its ability to replaced strontium which can then replace calcium. When plants absorb Strontium instead of calcium and animals eat these plants, there will be poor bone formation in the animals. The range of BBL-84,799 $\mathrm{mg} / \mathrm{kg} \mathrm{Ca}$ was recorded by the inorganic fertilizer samples.

Table 1 Elemental composition of inorganic fertilizer samples mg/kg by XRF method

\begin{tabular}{|c|c|c|c|c|c|c|c|c|c|c|c|c|}
\hline $\begin{array}{l}\text { SAMPLE } \\
\text { CODE }\end{array}$ & $\mathrm{Al}$ & $\mathrm{Ca}$ & $\mathrm{Cr}$ & $\mathrm{Cu}$ & $\mathrm{Fe}$ & $\mathrm{K}$ & $\mathrm{Mn}$ & $\mathrm{Ni}$ & $\mathrm{Si}$ & $\mathrm{Ti}$ & V & $\mathrm{Zn}$ \\
\hline CRP1 & BDL & BDL & 72 & 5 & 3,930 & 114,678 & 66 & 142 & 288 & 62 & 24 & 49 \\
\hline CRP2 & $\mathrm{BDL}$ & BDL & 32 & 7 & 853 & 133,814 & 34 & 72 & BDL & 113 & 2 & BDL \\
\hline CRP3 & 110,400 & 9,401 & 31 & 5 & 438 & 85,698 & BDL & 64 & 9,630 & 335 & BDL & BDL \\
\hline CRP4 & 79,580 & BDL & 24 & 2 & 9,676 & 34,776 & 118 & 48 & 17,640 & 1,773 & 33 & BDL \\
\hline CRP5 & 65,320 & 2,761 & 26 & 4 & 11,441 & 40,940 & 140 & 52 & 15,840 & 1,773 & 45 & BDL \\
\hline CRP6 & 59,800 & BDL & 0.040 & 8 & 7,874 & 142,462 & 10 & 64 & 7,110 & 1,327 & 51 & BDL \\
\hline CRP7 & BDL & $6,378.4$ & 0.047 & 5 & 4,076 & 1,104 & 139 & 54 & 816 & 119 & 52 & 98 \\
\hline CRP8 & 77,280 & 1,426 & 0.037 & 7 & 12,209 & 13,110 & 439 & 60 & 20,400 & 1,897 & 58 & 20 \\
\hline CRP9 & 5,520 & 84,799 & BDL & BDL & 3,770 & BDL & 220 & BDL & 1,608 & 55 & BDL & 23 \\
\hline Mean & 44,211 & 11,641 & 0.034 & 5 & 6,467 & 62,954 & 129 & 126 & 8,148 & 631 & 29 & 21 \\
\hline Range & $\begin{array}{l}\text { BDL- } \\
110,400\end{array}$ & $\begin{array}{l}0- \\
84,799\end{array}$ & $\begin{array}{l}\text { BDL- } \\
72\end{array}$ & $\begin{array}{l}\text { BDL- } \\
7\end{array}$ & $\begin{array}{l}853- \\
12,209\end{array}$ & $\begin{array}{l}\text { BDL- } \\
142,462\end{array}$ & $\begin{array}{l}\text { BDL } \\
-439\end{array}$ & $\begin{array}{l}\text { BDL } \\
-142\end{array}$ & $\begin{array}{l}\text { BDL- } \\
20,400\end{array}$ & $\begin{array}{l}55- \\
1,897\end{array}$ & $\begin{array}{l}\text { BDL } \\
- \\
58\end{array}$ & $\begin{array}{l}\text { BDL } \\
- \\
98\end{array}$ \\
\hline
\end{tabular}

BDL=Bellow detectable limit

Key:

CRP1= Sambuka four corner vital 15-15-15 NPK,

CRP2 Golden 15-15-15 NPK

CRP3 = AFCUTT 15-15-15 NPK,

CRP4= Tak 20-10-10 NPK

CRP5= Maishaho 20-10-10 NPK,

CRP6= Golden 20-10-10 NPK 
CRP7 = DAP (Diammonium phosphate),

CRP8 $=$ Tak Agro (Single Superphosphate 18\%)

CRP9= FSFC (Single Superphosphate 18\%)

Table 2: Statistical comparison of selected toxic elements in inorganic fertilizers determined by XRF method

\begin{tabular}{lllll}
\hline & $\mathrm{Cr}$ & $\mathrm{Si}$ & $\mathrm{Ti}$ & $\mathrm{V}$ \\
NAME & Mean \pm S.E & Mean \pm S.E & Mean \pm S.E & Mean \pm S.E \\
\hline Sambuka15-15-15 & $27.4 \pm 17.5 \mathrm{ab}$ & $1157.376 \pm 1101 \mathrm{a}$ & $273 \pm 260.86 \mathrm{~b}$ & $11.546 \pm 7.766 \mathrm{bc}$ \\
Golden15-15-15 & $14.199 \pm 9.4 \mathrm{abc}$ & $1061.376 \pm 1061 \mathrm{a}$ & $290 \pm 268.07 \mathrm{~b}$ & $4.836 \pm 4.043 \mathrm{bc}$ \\
AFCUTT15-15-15 & $21.466 \pm 8.1 \mathrm{abc}$ & $4271.376 \pm 2824 \mathrm{a}$ & $364 \pm 302.02 \mathrm{~b}$ & $13.396 \pm 6.180 \mathrm{bc}$ \\
Tak20-10-10 NPK & $11.633 \pm 7.9 \mathrm{abc}$ & $6941.376 \pm 4466 \mathrm{a}$ & $843 \pm 568.15 \mathrm{~b}$ & $14.393 \pm 9.479 \mathrm{bc}$ \\
Maishaho20-10-10 NPK & $19.366 \pm 7.3 \mathrm{abc}$ & $6341.376 \pm 4094 \mathrm{a}$ & $843 \pm 568.15 \mathrm{~b}$ & $23.606 \pm 9.915 \mathrm{bc}$ \\
Golden20-10-10 NPK & $16.949 \pm 11.1 \mathrm{abc}$ & $3431.376 \pm 2321 \mathrm{a}$ & $695 \pm 480.88 \mathrm{~b}$ & $20.493 \pm 13.228 \mathrm{bc}$ \\
DAP & $23.378 \pm 11.5 \mathrm{abc}$ & $1333.376 \pm 1178 \mathrm{a}$ & $292 \pm 268.97 \mathrm{~b}$ & $89.650 \pm 38.703 \mathrm{a}$ \\
TAK_Agrossp_18 & $33.033 \pm 10.8 \mathrm{a}$ & $7861.376 \pm 5039 \mathrm{a}$ & $2441 \pm 878.87 \mathrm{a}$ & $38.963 \pm 13.102 \mathrm{~b}$ \\
FSFCssp_18 & BDL & $536.00 \pm 339 \mathrm{a}$ & $18.19 \pm 11.5 \mathrm{~b}$ & BDL \\
\hline
\end{tabular}

Note: Means with the same letter are not significantly different at 0.05

\section{Conclusion}

The inorganic fertilizers analysed by XRF method have in them twelve different elements like $\mathrm{Cu}, \mathrm{Fe}, \mathrm{Ca}$ and $\mathrm{Zn}$ which are beneficial to plant health and growth and are considered safe for use on our croplands . However, Sambuka 15-15-15 had higher concentration of $\mathrm{Cr}$ than found in agricultural soils.

\section{Recommendations}

As much as it is recommended to monitor the environment for heavy metals to avoid land degradation and contamination, it is also important to monitor it for beneficial elemental depletion. From this study therefore, it is recommended that before Sambuka 15-15-15 is used, the land on which it is to be applied should first be tested for $\mathrm{Cr}$ to avoid $\mathrm{Cr}$ build up in the soil.

Recommended Sources and Minimum detectable limits

\begin{tabular}{|c|c|c|c|c|}
\hline \multirow[b]{2}{*}{ Element } & \multirow{2}{*}{$\mathrm{X}$-ray } & \multicolumn{2}{|c|}{ Sources } & \multirow{2}{*}{$\begin{array}{l}\text { Minimum } \\
\text { *detectable } \\
\text { limit wt \% }\end{array}$} \\
\hline & & Recommended & Possible & \\
\hline $\mathrm{Ca}, \mathrm{Sc}, \mathrm{Ti}, \mathrm{V}$ & $\mathrm{K}$ & $\mathrm{Fe} 55(20 \mathrm{mCi})$ & & 0.2 \\
\hline $\mathrm{Cr}$ & $\mathrm{K}$ & $\mathrm{Fe} 55(20 \mathrm{mCi})$ & $\mathrm{Pu}-238(30 \mathrm{mCi})$ & 0.2 \\
\hline $\mathrm{Mn}, \mathrm{Fe}, \mathrm{Co}, \mathrm{Ni}$ & $\mathrm{K}$ & $\mathrm{Pu}-238(30 \mathrm{mCi})$ & & 0.2 \\
\hline $\mathrm{Cu}, \mathrm{Zn}, \mathrm{Ga}, \mathrm{Ge}, \mathrm{As}, \mathrm{Se}$ & $\mathrm{K}$ & $\mathrm{Pu}-238(30 \mathrm{mCi})$ & Cd-109(1mCi) & 0.1 \\
\hline $\begin{array}{c}\mathrm{Br}, \mathrm{Rb}, \mathrm{Sr}, \mathrm{Y}, \mathrm{Zr}, \mathrm{Nb}, \mathrm{Mo}, \\
\mathrm{Ru}\end{array}$ & $\mathrm{K}$ & Cd-109(1mCi) & & 0.05 \\
\hline $\begin{array}{c}\mathrm{Rh}, \mathrm{Pd}, \mathrm{Ag}, \mathrm{Cd}, \mathrm{In}, \mathrm{Sn}, \mathrm{Sb}, \\
\mathrm{Te}, \mathrm{I}, \mathrm{Cs}, \mathrm{Ba}, \mathrm{La}, \mathrm{Tm}\end{array}$ & $\mathrm{K}$ & $\mathrm{Am}-241(3 \mathrm{mCi})$ & & 0.05 \\
\hline \multirow{2}{*}{$\begin{array}{c}\mathrm{Yb}, \mathrm{Lu}, \mathrm{Hf}, \mathrm{Ta}, \mathrm{W}, \mathrm{Re}, \mathrm{Os}, \\
\mathrm{Ir}, \mathrm{Pt}, \mathrm{Au},\end{array}$} & $\mathrm{K}$ & Co-57(1mCi) & $\begin{array}{l}\text { Gd-153(1mCi)(Yb to } \\
\mathrm{Bi})\end{array}$ & 0.3 \\
\hline & $\mathrm{L}$ & $\begin{array}{c}\mathrm{Pu}- \\
283(30 \mathrm{mCi})(\mathrm{Yb} \\
\text { to U }\end{array}$ & $\mathrm{Cd}$ & 0.2 \\
\hline 25 & oun & tistics, 10 secon & measuring time. & \\
\hline
\end{tabular}

References

[1]. Alloway, B.J. (1990). Heavy metals in soils: John Wiley and sons Inc. New York,

[2]. ATSDR -Agency for Toxic Substances and Disease Registry (2007).Toxicological profile for Arsenic. Department of Health and Human Services, Atlanta, United States

[3]. Brigden, K., Stringer, R., \& Santillo, D. (2002).Heavy metals and radionuclide contamination of fertilizer products and phosphogypsum waste products by Lebanese Chemical Company, Lebanon GRL, University of Exeter, UK.

[4]. IARC-International Atomic Radiation committee, (1994), Special report: Policy- a review of human carcinogens Part C: Metals, Arsenic, dust http: www.thelancet.com/oncology.

[5]. Kabata-Pendias, A \& Pendias, H. (1992).Trace Elements in soils and plants, $2^{\text {nd }}$ edition CRC press, Boca Raton, Florida, 315.

[6]. Munkholm, L. J. (1992). The status of trace Elements in some Nigerians savannah soils, a thesis (unpublished) submitted to the Chemistry Department of the Royal Veterinary and Agriculture University, Copenhagen, Denmark

[7]. Ogunleye, P.O. Mayaki, M., C. \& Amapu, I. Y. (2001). Radioactivity and heavy metal composition of Nigerian phosphate rocks: possible environmental implications, Journal of Environmental Radioactivity 62: 39-48

[8]. Santos, A.J.G., Mazzilli, B.P., Fa'varo, D.I.T. \& Silva, P.C. (2005). Partitioning of radionuclides and trace elements in phosphogypsum and its source materials based on sequential extraction methods. Journal of Environmental Radioactivity Series Radionuclides in the Environment: A Review Journal of Environmental Quality, the production of triple superphosphate (TSP) fertilizer and phosphoric acid. Fertilizer to the general Assembly, with annexes, United Nations, New York

[9]. Shaffer, M. (2001), Waste Lands: The Threat of Toxic Fertilizers, CALPIRG Charitable Trust, the State PIRGs

[10]. WHO- World Health Organization (1992) Cadmium: Environmental Health Criteria 135. Cadmium ISBN 9241571357 